\title{
Den sista striden och den framtida freden
}

Anders Hultgård

Uppsala universitet, Sverige

\section{Inledning}

Temat krig och fred i norröna traditioner låter sig även föras över till en eskatologisk kontext. Den stora slutstriden i Ragnarök och den förnyelse av världen som följer på undergången kan sägas bilda de två motpolerna krig och fred.

Föreställningen om en sista konfrontation mellan goda och onda makter möter oss i flera religioner. I den skandinaviska ragnaröksmyten utgör den sista striden den dramatiska kulmen i det skeende som leder fram till världens undergång, men kampen mellan goda och onda makter tar i Norden en egenartad och märklig vändning. Tor, Oden och Frö, de stora gudarna som man har tillbett genom århundraden faller i kampen mot sina motståndare vilka å sin sida inte heller överlever. Det är främst en strid där gudar möter demoniska väsen med två monsterdjur och en förrädare i spetsen. Enhärjarna, krigarna från Valhall, hjälper gudarna, men det framgår inte klart om människor också kämpar på gudarnas sida.

Källmaterialet till föreställningarna om Ragnarök är egentligen ganska magert, särskilt i jämförelse med den breda eskatologiska tradition som vi möter i tidig judendom och kristendom samt i iransk religion. ${ }^{\mathrm{I}}$ Vqluspá, några strofer i Vafprúðnismál och i Hyndluljóð samt Snorres framställning i kapitlen 5 I till 53 i Gylfaginning ger oss en uppfattning om den kosmiska eskatologi som åtminstone under senare delen av vikingatiden traderades i västnordiska miljöer. Därtill kommer anspelningar i andra edda-dikter; några få återfinns även i skaldedikter, främst Eiríksmál

Hur du refererar till det här kapitlet:

Hultgård, A. 20I6. Den sista striden och den framtida freden. I: Rydving, H. and Olsson, S. (red.) Krig och fred i vendel- och vikingatida traditioner, s. 22I-248. Stockholm: Stockholm University Press. DOI: http://dx.doi. org/IO.I6993/bah.j. License: CC-BY 4.0 
och Hákonarmál. Att skildringen av Bråvallaslaget hos Saxo och i Sogubrot skulle återgå på en eskatologisk myt är föga troligt. ${ }^{2}$

Jag försöker se texterna om Ragnarök, särskilt Vqluspá, som nedslag av en muntligt baserad tradition som hållits levande $\mathrm{i}$ varje fall fram till I 200-talet. ${ }^{3}$ Därefter tycks den ha stelnat och blivit blott en litterär tradition med antikvariska förtecken; ett exempel på det är den så kallade Eptirmáli II i handskrifterna till Skáldskaparmál (dock inte Codex Upsaliensis), där det sägs: "Men det som de [asarna] gör till långa berättelser om Ragnarök, det handlar egentligen om det Trojanska kriget".

Mitt synsätt på föreställningarna om Ragnarök som uttryck för en mångfacetterad muntlig tradition innebär att mytens varianter inte spelas ut mot varandra utan ses som likvärdiga delar av en levande tradition. ${ }^{4} \mathrm{Jag}$ behandlar även de tre text-strängarna till Voluspá som självständiga varianter och jag lägger inte ner arbete på att vaska fram en ursprunglig skriftlig version. ${ }^{5}$ Det är annars regel i de textutgåvor och översättningar som presenteras av Voluspá. ${ }^{6}$ Inte heller vill jag tala om interpolationer i texten som man till exempel gör med strof 65 i Hauksbóks version.

För att kunna ringa in den skandinaviska ragnaröksmytens särprägel och bedöma frågan om dess ursprung måste vi sätta in den i ett större sammanhang. Det första är den medeltida västnordiska kultur som faktiskt såg till att bevara ragnaröksmyten till eftervärlden. En jämförelse med kristendomens universella eskatologi, särskilt i de former den nådde Skandinavien under vikingatid och medeltid, är därför en nödvändighet. Runinskrifter och tidiga folkspråkliga texter utgör härvidlag de viktigaste källorna. I ett bredare perspektiv framträder jämförelsen med den iranska religionen som särskilt intressant eftersom den har en lång tradition av föreställningar kring världens slut och förnyelse. ${ }^{7}$ Den tillhör dessutom samma typ av etnisk gemenskapsreligion som den skandinaviska. Spår av en kosmisk eskatologi är synliga också i keltisk religion liksom i den hellenistisk-romerska världens olika traditioner.

\section{Sammandrabbningen}

Det väldiga uppbådet av fientliga makter som texterna beskriver pekar fram mot en lika väldig slutstrid, och allt tal om "gudarnas 
öde", ragna røk, ${ }^{8}$ som ju betyder deras sista kamp och undergång, skapar en förväntan om en nästan episk framställning av detta avgörande moment. Märkligt nog är skildringen av den sista striden ganska fattig på utmålande detaljer i de till oss bevarade delarna.

Traditionen är samstämmig om att Oden kämpar mot Fenrisulven och Tor mot Midgårdsormen. Dessa fyra framstår som huvudaktörerna och deras sammandrabbning blir omnämnd i de flesta källor. ${ }^{9}$ Störst roll spelar mötet mellan Oden och Fenrisulven liksom det hjältedåd som Vidar utför när han dödar ulven. ${ }^{\text {10 }}$ De formuleringar traditionen använder visar att man tänker sig Oden som den som tar initiativet i striden: ferr við úlf at vega, 'han går fram (eller: "rider fram") för att kämpa mot ulven' (Voluspá 53), och stefnir hann móti Fenrisúlf, 'han styr (hästen) mot ulven' (Gylfaginning 5 I: 5). Själva kampen beskrivs inte närmare, bara att Oden dör.

Att guden faller uttrycks i Voluspá på så sätt att hans död speglas genom gudinnan Frigg, Odens gemål. Först vänds uppmärksamheten mot hennes sorg: "då blir för Hlin en andra sorg verklighet" och sedan omnämns Oden med en poetisk omskrivning, som även den röjer hennes känsla för guden (strof 53): "Då skall Friggs glädje (Friggiar angan) falla". Andra delar av traditionen låter oss dock veta att Oden dör genom att Ulven slukar honom:

úlfr gleypa mun Aldafoðr,

Ulven skall sluka Människors Fader (Vafprúðnismál 53)

ok svelgr hann allan Sigfoður,

och han [Ulven] sväljer Stridsfader hel och hållen (Lokasenna 58 ) úlfrinn gleypir Óðin, verðr pat hans bani

Ulven slukar Oden, och det blir hans död (Gylfaginning 5 I: 6)

(Min övers.)

Guden Vidar figurerar i källorna mest för sitt hjältedåd i Ragnarök. Det Snorre har att säga om honom i sina gudaporträtt inskränker sig till några få utsagor (Gylfaginning, kap. 29). Han kallas "den tystlåtne asaguden" (binn pogli áss) och gudarna har mycket hjälp av honom i alla trångmål. Utsagan att han bär en tjock sko (hann hefir skó pykkan) pekar fram mot hans roll i världsdramat. Den omtalas i tre edda-dikter, nämligen Grímnismál strof I7, Vafprúdnismál strof 53 och Veluspá strof 55 (se ovan s. 203) och utförligare i Snorres Edda, 
Gylfaginning kap. 51: 6. Grímnismál skildrar de olika gudarnas boningar och vad de där sysslar med (stroferna 4 till 17 ). Vidar bor i sitt land, Vidi, som är beväxt med buskar och högt gräs och där rider den djärve guden omkring och inväntar stunden då han ska hämnas sin fader Oden. Hur hämnden går till omtalas i andra källor. När Oden har fallit, går Vidar fram för att kämpa mot Fenrisulven och lyckas också döda odjuret. Det sätt på vilket guden övervinner Ulven skiljer sig mellan de olika traditionsgrenarna. Enligt Voluspá sticker han sitt svärd djupt i Fenrisulvens hjärta, medan Vafprúðnismál säger att han klyver ulvens käftar. På den senare linjen går även Snorres Edda som låter Vidar stiga med ena foten på ulvens nedre käke. På den foten har han sin skyddande sko. Med ena handen griper han tag i ulvens övre käke och sliter isär hans gap. Här använder sig Vidar tydligen inte av något vapen såsom han gör i Voluspá och av ordvalet att döma också i Vafprúđnismál där verbet klyfja snarast antyder bruket av ett svärd.

Omnämnandena av Tors kamp mot Midgårdsormen skiljer sig något åt, såväl i den poetiska traditionen som i de två versionerna av Snorres Edda. Klart är att guden dräper Midgårdsormen men själv dör av det etter ormen sprutar mot honom. De nio steg Tor tar innan han faller utgör en karakteristisk detalj i skildringen av den väldiga tvekampen och finns med i alla textvarianterna. Egendomligt nog är det gudens kamp och död som de bevarade delarna av myten uppehåller sig vid, medan hans motståndares öde bara flyktigt omtalas i två av traditionssträngarna. Uppsala-eddan nämner helt kort att Tor dödar Midgårdsormen, Pórr drepr Miðgarðsorminn, och Voluspá (S) betonar bara gudens rasande kampsinne: er af móði drepr Miðgarðs véurr, men här måste vi underförstå att objektet är Midgårdsormen. Att traditionen på denna punkt varit fylligare ger Voluspá (H) en vink om som ensam av de poetiska varianterna antyder den skräckinjagande ormens framryckning:

ginn lopt yfir lindi jarðar, gapa yggs kiaptar orms Jordens band [= Midgårdsormen] gapar upp i luften, den skrämmande ormens käkar öppnar sig (strof 56a) ${ }^{\text {II }}$

(Min övers.)

Lokasenna strof 58, liksom Gylfaginning 5I: 6 (Rs W T), antyder att Tor även tänker strida mot Fenrisulven, men av olika skäl inte lyckas förverkliga sin avsikt. 
Guden Frö och hans strid mot Surt intar en mer undanskymd plats, i varje fall i de poetiska texterna. ${ }^{\mathrm{I2}} \mathrm{I}$ VQluspá sägs endast att Frö ska kämpa mot Surt och formuleringen är densamma i alla tre varianterna (R, H, och S): en bani Belia at Surti (med underförstått vega, 'kämpa', från strofens första del). Lokasenna känner till litet mer. Guden lämnade bort sitt svärd i utbyte mot Gymes dotter och vet inte hur han ska strida när undergången nalkas:

Med guld lät du köpa Gymes dotter, och du lämnade (seldir) så bort ditt svärd, men när Muspells söner rider över Mörkskogen, vet du då, olycklige, hur du skall kämpa? (strof 42)

(Min övers.)

Skírnismál omtalar att svärdet har den egenskapen att det svingar sig självt i strid mot jättarnas släkte (strof 8-9). Snorre har knappast något nytt att meddela. Frö faller efter en hård kamp eftersom han saknar sitt goda svärd som han gav till Skirne (Gylfaginning 5 I). Vi får inte veta vad som hände med svärdet sedan Skirne fick det $\mathrm{i}$ sin hand och inte heller vad han skulle använda det till. Det ligger nära till hands att anta att han skulle utnyttja det som ett hot inför jätten Gyme. Man kunde vidare vänta sig att han skulle lämna tillbaka svärdet till Frö efter uträttat uppdrag, men därom tiger källorna. Det kan bero på att den till oss bevarade myten är ofullständig. Gudens motståndare, eldsjätten Surt, överlever åtminstone i detta skede och hans död nämns inte explicit. Den får man väl förutsätta sker i den allmänna världsundergången. Vad gäller enviget mellan Tyr och Garm befinner vi oss på mer osäker mark men det vore fel att utesluta den möjligheten att Snorre hämtat motivet från tidigare tradition. ${ }^{\mathrm{I} 3}$

De poetiska texterna omtalar bara de tre huvudgudarnas kamp och undergång och Vidars hjältedåd, medan Snorre för in ytterligare två envig, det ena mellan Heimdall och Loke och det andra mellan Tyr och Garm. Det är tveksamt i vilken mån Snorres uppgifter här bygger på äldre tradition. ${ }^{14}$ Föreställningen att Heimdall möter Loke i den sista striden behöver inte vara ett drag tillagt av Snorre. Dessa två gudomar har kämpat mot varandra förr, som framgår av en strof hos Ulf Uggason (Húsdrápa 2) och striden gällde då vad diktaren kallar hafnýra fogru, 'den fagra havsnjuren', av Snorre tolkat som gudinnan Fröjas halssmycke, 
Brísingamen. ${ }^{15}$ Kanske tänkte man sig att denna strid utspelades i en mytisk urtid och att den skulle äga rum igen på ett mer slutgiltigt sätt i den yttersta tiden.

\section{Den kristna kontexten}

Som jag påpekade i inledningen har traditionen om Ragnarök nått oss genom förmedling av den medeltida kristna kulturen på Island och i Norge. Kristendomens eskatologiska föreställningar innefattar också en framtida konfrontation mellan onda och goda makter som kan ha färgat framställningen av den sista striden i Ragnarök. Det är Uppenbarelsebokens skildring som främst har kommit att forma den kristna bilden. Kampen sker på flera plan, i olika om-

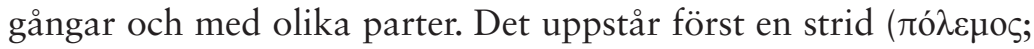
Vulgata: proelium) i själva himlen mellan Mikael och hans änglar å ena sidan och draken, som kallas Djävul och Satan, och hans änglar, å den andra sidan (Upp. I 2: 7-9). Draken förmår inte hålla stånd, och det finns inte heller någon plats för honom i himlen och därför kastas han och hans änglar ned på jorden. Ett annat avsnitt av Uppenbarelseboken antyder till en strid på Guds stora domedag. De orena andar som släpps ut ur drakens, odjurets och den falske profetens mun samlar kungarna i hela världen till "den plats som på hebreiska heter Harmagedon" (Upp. I6: I3-16). ${ }^{16}$ Huruvida kungarna skall kämpa mot varandra eller tillsammans mot Kristus och de rättfärdiga får vi inte veta. Tydligen har Uppenbarelsebokens författare inte funnit något större intresse av att mer utförligt skildra en sammandrabbning vid Harmagedon utan nöjt sig med en antydan.

I en andra omgång stiger en ängel ned från himlen, binder Satan och kastar honom i avgrunden, där han ska hållas bunden i tusen år (Upp. 20: $\mathrm{I}-3)$. Sedan skall han dock släppas lös om än för en kort tid. Formuleringen antyder att hans frisläppande är förutbe-

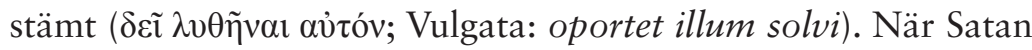
så kommer loss, samlar han ihop Gog och Magogs otaliga skaror till krig. De stiger ut på jordens vida yta och omringar de goda

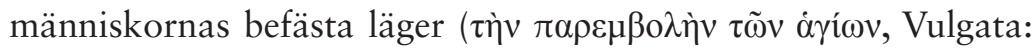
castra sanctorum) och "den älskade staden”, Jerusalem, men då faller eld från himlen och bränner upp fienderna. Djävulen som 
förledde människorna kastas ned i sjön av eld och svavel tillsammans med vilddjuret och den falske profeten. Där ska de plågas dag och natt i eviga tider (Upp. 20: 7-10). Det fientliga mötet står mellan två grupper av mänskliga aktörer om än med gudomliga och demoniska ledare i bakgrunden men det kommer inte till någon egentlig strid. De passiva verbformerna "kastades" och "skall plågas" antyder att det är Gud eller Kristus som bestämmer straffdomen. De enda egentliga strider som nämns är den mellan Mikael och Draken-Djävulen vilken utspelar sig i himlen, och den som antyds skall ske vid Harmagedon.

En annan tidig eskatologisk text, 2 Thessalonikerbrevet, kap. 2: I-I 2, tänkte sig att innan Jesus kommer tillbaka så måste ett stort avfall ske och en gestalt kallad "den Laglöse" (o ơvouos; Vulgata: ille iniquus) uppenbara sig. ${ }^{17}$ Denne är utsänd av Satan själv och ställer sig förmätet upp mot allt som är gudomligt och heligt, men vid sin återkomst skall Jesus döda honom. Denna text har bidragit till bilden av Antikrist, en gestalt som växer fram först under det andra århundradet då de spridda traditionstrådarna vävs samman till en legend i kyrkofadern Hippolytos framställning. ${ }^{18}$

I den fornvästnordiska religiösa litteraturen har Uppenbarelsebokens omtalande av Satans utkastande från himlen och hans slutliga besegrande lämnat få avtryck, liksom skildringen av "den Laglöse" i 2 Thessalonikerbrevet. ${ }^{19}$ Någon hänvisning till kungarnas strid vid Harmagedon finns mig veterligt inte heller. Däremot har föreställningarna om Antikristgestalten och övervinnandet av honom fått betydligt större uppmärksamhet. ${ }^{20}$ Hans besegrande utgör en del av slutkampen mellan gott och ont. Efter att ha tillskansat sig herravälde över världen, befaller han att han skall dyrkas som Gud. ${ }^{21}$ Henok och Elias blir då utsända att träda upp mot Antikrist, men kommer att bli dräpta av honom. Det framgår inte att detta sker genom en strid. Troligtvis uppfattade man det så, att de båda profeterna lät sig dödas utan väpnat motstånd. Den Isländska Homilieboken (IHB) omtalar att Elias ska komma tillbaka vid världens slut (í niðlagi pessar veraldar) för att träda upp emot Antikrist men han kommer att dö av den tortyr Antikrist utsätter honom för (IHB 47, v. 2 I-23). Antikrist skall slå upp sitt läger på Oljeberget i Jerusalem för att bekämpa de rättfärdiga, men där finner han en bråd död genom att bli dräpt av Guds muns andedräkt (með anda muns Guðs). ${ }^{22}$ Samma 
föreställning ligger bakom den Isländska Homiliebokens utsaga att Gud ska slå (lýstr) Antikrist med blixten (með eldingu) så att han får en bråd död (ok verðr hann bráðdauðr; IHB 7I, r. 34-35).

En annan tradition som också den tidigt spreds i Skandinavien säger däremot att det är ärkeängeln Mikael som vid världens slut ska kämpa mot Antikrist och dräpa denne:

en af pví er svá á bókum sagt at i enda heims pessa skyli Mikael berjask á mót ok í gegn Antikristi ok drepa hann; pví at pat er makligt at sá er i ofmetnaði vildi magnask i gogn Guði, verði af peim engli drepinn er pat sýnir i nafni sínu at engi er slikr sem Guðð ${ }^{23}$

och därför är det sagt så i böckerna att vid denna världens slut skall Mikael kämpa mot Antikrist och dräpa honom, ty det är passande att han, som i övermod ville göra sig stor gentemot Gud, blir dräpt av just den ängel som med sitt namn visar att ingen är såsom Gud.

(GNH I 37: 4-8; min övers.)

I den fornhögtyska dikten Muspilli från 80o-talet antar konfrontationen mellan Elias och Antikrist nästan kosmiska drag. Det ska ske en väldig kamp (fht. wīg) dem emellan. De stridandes makt och sakens viktighet betonas och i bakgrunden står ännu starkare krafter:

kempfun sint sō kreftīg, diu kōsa ist sō mihbil, Elias strìtit bi den èwīgon līb wili den rehtgernōn daz rīhhi gistarkan bidiu skal imo helfan der himiles giwaltit; der antichristo stēt bi demo altfiante, stēt bi demo Satanase, der inan farsenkan skal ${ }^{24}$

Kämparna är så väldiga, saken är så stor, Elias strider för det eviga livets skull, han vill att riket skall bli starkt för de rättfärdiga, därför kommer Han som råder över himlen att hjälpa honom. Antikrist står vid den gamle Fiendens sida, han står vid Satans sida som skall förgöra honom (Antikrist). ${ }^{25}$ (Muspilli $40-45$; min övers.)

Antikrist kommer därför att besegras (sigilōs werdan) och sårad falla ned på kampplatsen (in deru wigsteti wunt bifallan). Men inte heller Elias går oskadd ur striden. Det sägs att han blir sårad 
(arwartit) och att hans blod droppar ned på jorden. Den kosmiska aspekten på denna tvekamp blir tydlig också här genom att det är denna händelse som sätter i gång världsbranden (Muspilli 45-5I).

Skildringen i Muspilli av striden mellan Elias och Antikrist har en karaktär som inte helt kan förklaras utifrån en kristen bakgrund. ${ }^{26}$ Det är framför allt det påtagliga krigiska draget och att konfrontationen utformas som en väldig tvekamp på ett kosmiskt plan som faller i ögonen. Detta återspeglar säkerligen ett germanskt inflytande. Av allt att döma riktade sig dikten till krigaradeln i 800-talets Bayern, och till kretsar som stod kung Ludvig nära. ${ }^{27}$

Allmänt sett ägnar dock den universella kristna eskatologin såsom vi kan följa den in i medeltiden föga uppmärksamhet åt en strid mellan goda och onda makter. I stället för kampscener är det föreställningen om en dom med dess juridiska aspekter som behärskar skildringarna av världens slut. De folkspråkliga texterna, både de fornengelska och de fornvästnordiska, visar detta med full tydlighet. Man ska samlas till rannsakning och dom, inte till strid. En predikan i Gamal Norsk Homiliebok (GNH) frammanar de tre härskaror ( $f y l k i$ ) som ska komma samman på domedagen (GNH I68: 22-25): allt det heliga himmelska folket under ledning av vår herre (allr inn helgi himneskr várs dróttins lýðr), vidare alla människor (alt mannkyn) och som den tredje skaran, "alla djävlar från helvetet" (allir djoflar ór helvíti). ${ }^{28}$ Texten ger dock ingen antydan om att detta möte skulle mynna ut $\mathrm{i}$ en krigisk sammandrabbning.

Även Satan och hans anhang får sitt straff i den Yttersta domen men knappast genom att besegras i strid. Elucidarius (s. I36; III: $74)^{29}$ säger kort att

när domen är avslutad (at loknum dómi) skall djävulen störtas ned i ett fängelse av eld och svavel (steypisk $i$ dyflissa elds ok brennusteins).

(Min övers.)

Jämförelsen mellan den fornskandinaviska ragnaröksmyten och den kristna eskatologin visar på klara skillnader. De skandinaviska gudarna för med sig sina speciella vapen i slutstriden. Frö har ju lämnat bort sitt excellenta svärd men Oden rider fram mot fiendehären med sitt spjut Gungnir och Tor bär sin hammare Mjollnir. 
I kristen tradition sägs det oftast bara att Gud, Kristus / Jesus eller Mikael övervinner eller förintar sina motståndare utan att man anger hur detta går till. I de fall man gör det, är det andra medel än vapen som kommer till användning. Munnens andedräkt, blixten, en bländande glans som förintar eller en kvalfull avrättning. ${ }^{3 \circ}$

Den kristna eskatologin känner visserligen enskilda konfrontationer såsom striden i himlen mellan ärkeängeln Mikael och draken, och Mikaels kamp mot Antikrist. Kristi nedstigande i dödsriket och övervinnande av Satan och hans demoner sker inte genom en kamphandling och är inte heller förlagt till den yttersta tiden. ${ }^{3}$ Kristen tradition målar inte upp någon stor sammandrabbning. En sådan finner man däremot i iransk religion och den visar tydliga beröringspunkter med fornskandinavisk tradition.

\section{Den iranska traditionen och motivet med tvekampen}

En föreställning som på ett särskilt sätt binder samman ragnaröksmyten och den iranska kosmiska eskatologin är att slutstriden sker i form av en tvekamp mellan de främsta gudarna och deras demoniska motståndare. Detta drag är fast förankrat i den iranska traditionen och det tidigaste belägget finner vi en avestisk kulthymn, Yašt I9, tillägnad xvaranah-, 'lyckoglansen'. Dess komposition kan dateras till senast 500-talet före vår tideräkning. ${ }^{32}$

Den slutlige befriaren, saošyant'en, Astvat-Arta, skall uppenbara sig från Kansaoya-sjön och bära med sig sitt vapen som av allt att döma är en stridsyxa, fornir. vazra-.33 Det är en tydlig motsvarighet till guden Tors Mjollnir liksom till Indras 'åskvigg', vájra(etymologiskt besläktat med vazra-), och man ger detta vapen också samma status och uppmärksamhet. Det har burits av andra heroiska gestalter i Irans mytiska historia såsom kavi Haosravah och kavi Vištāspa och bringat dem seger. Med detta vapen skall Astvat-Arta skaffa bort ondskan, druj-, ur världen, när han besegrar den Onde Anden, ayramainyu-, som vanmäktig viker tillbaka. De gudomliga väsen som omger den högste guden övervinner var och en sin motståndare. Vohu Manah ('den Goda Tanken') besegrar Aka Manah ('den Onda Tanken'), det rätta Ordet besegrar det förvrängda Ordet, Haurvatat besegrar Hungerdemonen och Amərətat Törstens demon. De nämnda väsendena utgör egentligen 
personifierade abstraktioner men fungerar såsom verkliga gudomar och demoner.

I den efterföljande traditionen dyker motivet med en sista tvekamp mellan gudomar och demoner upp flera gånger, och inte endast i Bundahišn som man vanligtvis citerar. ${ }^{34}$ En liknande framställning av den sista sammandrabbningen ger pahlavi-texten Zādsprams samling (Wizìdagīhā $\bar{\imath}$ Zādspram), där ytterligare gudomliga väsen och motståndare uppträder vid sidan av de redan kända. Dock utelämnar man här kampen mellan Ohrmazd och Ahreman (den återfinns på annat ställe i texten):35

Var och en av de lysande gudaväsendena (rōšnān) skall slå (zanéd) sin egen motståndare. Så skall Vahuman (slå) Akoman, Ardvahišt Indar, Šahrevar Savur, Spandarmad Nanghaiti, Hordad och Amurdad (skall slå) Tauriz och Zairiz, Boskapens Ande (Gōšsurwan) skall slå Ulvdemonen (Druz ì gurg-tōhmag), Kraftens ande (skall slå) Kraftlösheten som (uppkommer) ur åldrande.

(Wizìdagīhà ̀̃ Zādspram 35: 37; min övers.)

Andra varianter av myten om den stora slutstriden, där även tvekampsmotivet skymtar, finner man på flera ställen i den iranska traditionen. Ett gott exempel ger den medelpersiska apokalypsen Zand $\bar{\imath}$ Wabman Yasn redigerad på 800-talet, men byggd på långt äldre material: ${ }^{36}$

Pišyotan, Vištaspa-sonen, går fram mot det stora avgudatemplet (uzdēszār ì wuzurg), nästet för den Onde Anden och för Khešm med blodig klubba; alla demoner och lögnvarelser av ond härkomst skall hamna i det djupa mörkret, i helvetet. De (Pišyotan och hans följeslagare) förstör detta avgudatempel genom den strålande Pišyotans strid ( ham-kōxšišnīh). Och jag, skaparen Ohrmazd, skall komma tillsammans med de Heliga Odödliga (Amahraspandān) till berget Hukairyat och jag skall befalla de Heliga Odödliga: "träd fram och gå den strålande Pišyotan till hjälp". Mihr med vida betesland, den snabbe Sroš, den sannfärdige Rašn, och Aštad, hon den segerrika, och de Mazda-troendes Lyckoglans (Xwarrah), (som är) den starke återupprättaren av ordningen i världen, vi alla skall på min, Skaparens, maning komma till den strålande Pišyotans värn och hjälp. De skall slå ned demonerna, mörkrets avkomma.

(Zand $\bar{\imath}$ Wahman Yasn VII: 26-30; min övers.) 
För att beteckna själva kampen används gärna ordet kōxšišnīh eller ham-kōxšišnīh vilket anger en strid man mot man. Den iranska traditionen omtalar även andra aspekter av den sista striden. När tre månader återstår till de dödas uppståndelse kommer "den stora striden" (ān wuzurg ardīg) att äga rum mellan gudarna och de onda makterna. Början av denna sista (abdom) strid blir uppenbar genom att människorna ser konturerna av en gudom (mēnōg) ridande på en lågande häst avteckna sig mot den mörka natthimlen. De blir då förvissade (abēgumān bawēnd) om att segern över ondskan är nära. Det sägs även att denna sista strid mellan de livgivande och förgörande makterna kommer att likna den som ägde rum då skapelsen tog form (Wizìdagīhā $\bar{\imath}$ Zādspram 34: 52-54).

\section{Ragnaröksmytens sociala förankring}

Det var säkerligen flera olika miljöer som bar upp traditionen om Ragnarök. Här skall jag endast lyfta fram en grupp för vilka myten om den stora slutstriden tycks ha spelat en viktig roll. Att kämpa på gudarnas sida i Ragnarök måste ha varit en tilltalande tanke för den skandinaviska aristokratin. Dikterna Eiríksmál och Hákonarmál från 900-talet vittnar om den ära som följde med ankomsten till Valhall och att bli välkomnad av Oden. Man kom också med i enhärjarnas skara och skulle en gång få delta i den sista striden mot gudars och människors fiender. ${ }^{37}$ Att denna tro varit stark kan man sluta sig till genom att de båda dikterna så tydligt betonar ett "hedniskt" tema trots att de båda kungar som hyllas, Erik blodyx och Håkon den gode, hade antagit kristendomen. ${ }^{38}$

En liknande föreställning om att delta i en sista ärofull strid fanns kanske bland elitära grupper hos kelterna på Irland. En av de tidigaste texterna om Patriks missionsverksamhet, Tiréchans notiser från 600-talet (kap. I2), har ett förbisett ställe som kan vara relevant i vårt sammanhang. När Patrik anländer till Tara möter han kung Loíguire som vägrar att anta den kristna tron och hänvisar till sin far Níalls önskan att bli begraven på höjderna i Tara och att kungen och hans män också vill bli det på samma sätt. De skall nämligen ligga ansikte mot ansikte med sina vapen beredda för den dag druiderna kallar erdath och som biskop Tiréchan förklarar motsvara den kristna domedagen, apud 
magos, id est iudicii diem Domini, 'hos druiderna betyder detta Herrens domedag'. ${ }^{39}$ Det är rimligt att tolka denna utsaga som en antydan till att de som begravdes på detta sätt skulle invänta en sista strid mellan goda och onda makter.

\section{Undergång och seger}

Det mest uppseendeväckande med ragnaröksmyten är som jag antydde i början att de stora gudarna faller i slutstriden. Men innebär detta ett nederlag och att ondskans makter triumferar? Så är långtifrån fallet och man kan med starka skäl i stället tala om en seger för den goda sidan. ${ }^{\circ}$ De mest fruktade fienderna, Fenrisulven, Midgårdsormen, Loke och hans skaror av jättar blir alla dödade. Flera av gudarna överlever uppenbarligen både striden och den allmänna undergången såsom Snorre påpekar:

Vidar och Vale lever, ty havet och Surtsbranden har inte skadat dem, och de bor på Idavallen, där förr Asgård stod.

(Gylfaginning, kap. 53; min övers.)

Vidar är också den som har övervunnit Ulven. Även andra gudar som överlevt världsbranden dyker upp i den nya världen. De goda makterna har inte förlorat. Ser man saken så, blir skillnaden på denna punkt mot iransk, och för den del kristen eskatologi, inte så avgörande.

\section{Den nya världen}

Efter den sista striden följer i skandinavisk mytologi den stora världsbranden och undergången som innebär att den gamla jorden förbränd sjunker ned i havet. Den föds dock igen i ny gestalt och världen blir förnyad. Skildringen av detta skeende är i jämförelse med uppmarschen till slutstriden och själva drabbningen mer kortfattad. ${ }^{4}$

Vilka drag i förnyelsen av världen är det som den skandinaviska traditionen särskilt lyfter fram? De främsta gudarna har försvunnit i Ragnarök, vilka egendomligt nog var de som i verkligheten var de rituellt mest dyrkade, men andra träder i deras ställe. Balder och Höder skall återvända från dödsriket och beträffande Oden och 
Tor är det andra generationens gudar som nu tar plats. Vidar och Vale, Odens söner, skall bo på gudarnas heliga platser och Mode och Magne, Tors söner, skall äga Mjöllner. ${ }^{42}$ Man kan fråga sig varför Tors fruktade vapen skall föras över in i den nya världen, där de fientliga makter guden bekämpade inte längre finns. Mjöllner måste ha en annan funktion och det förefaller som om den skall bevaras som en viktig symbol men nu inte längre för strid. Mycket talar för att hammaren också kunde användas till annat än att vara ett vapen. Prymskviða antyder att den svingades i bröllopsritual, och de många vikingatida amuletter i form av Torshammare, bilder av hammare på runstenar, liksom Kvinneby-amulettens inskrift, pekar på den betydelse detta föremål hade som en mäktig skyddssymbol. ${ }^{43}$ Formeln Pōrr vīgi, 'Tor vige', som återfinns på några runstenar i Danmark och Sverige, har säkerligen också uttalats i den verkliga kulten. ${ }^{44}$

De kultiska inslagen i den nya värld som kommer efter Ragnarök är påfallande och uppenbarligen kunde man inte tänka sig en ny värld utan gudomliga väsen och någon form av kult. De nya gudarna skall finnas på de gamlas kultplatser, deras vi'n (fvn. vé). Mjöllner kommer att ha kvar sin roll som kultsymbol. Höner kan i sin egenskap av offerpräst välja det träd (blautviðr R, blutviðr $\mathrm{H}$ ) från vilket kvistarna till orakelritualet skall hämtas.45

Vid sidan av de rituella inslagen lägger den skandinaviska traditionen stor vikt vid förnyelsen av kosmos. Jorden stiger ånyo upp ur havet, för all framtid grönskande. Den är inte skapad på nytt utan det är den gamla jorden som nu får tillbaka sin friskhet och grönska. ${ }^{46}$ Diktaren av Voluspá manar fram en bild av ett orört landskap med fjäll, och strömmande vatten (strof 59). Örnar flyger högt ovan och fångar fisk. ${ }^{47}$ Man har pekat på likheter med flera versrader i Tryggðamál, och det ligger säkerligen en gemensam förkristen föreställning om världen och rummet bakom naturbilderna i VQluspá, strof 59, och Tryggðamál.48

Denna fascination inför tanken på en förnyelse av naturen saknas i den kristna eskatologin. Egendomligt nog verkar den kristna traditionen inte haft något större intresse av att skildra den nya jorden och den nya himlen. Motivet slås visserligen an i Uppenbarelseboken 2I med orden "jag såg en ny himmel och en ny jord", men i stället är det skildringen av det nya Jerusalem 
som får all uppmärksamhet. ${ }^{49}$ Naturbilderna finner vi i stället i beskrivningarna om paradisets beskaffenhet. Så är också fallet i de tidiga folkspråkliga texterna vilka, så långt jag sett, aldrig skildrar den nya jord som skall skapas. Det är i stället bilder av den nya staden, det himmelska Jerusalem, och av paradiset som om och om igen dyker upp. Judisk och kristen tradition beskriver gärna det tillstånd av fred och social harmoni som skall råda efter domen och undergången men sådana aspekter saknas i den skandinaviska myten.

I den iranska traditionen är det liksom i den skandinaviska inte fråga om en nyskapelse av kosmos utan om en rening och förnyelse av världen. Denna frašō.karati (mir. frašgird) framställs gärna som ett offerritual, en yasna, med den siste fullkomnaren, saošyant'en, som offerpräst (Bundahišn 34: 23; Wizìdagīhā ̄ Zādspram 35: I 5-I7). Överhuvudtaget är det rituella perspektivet på världsförnyelsen påtagligt. Den iranska myten innehåller inslag som påminner om Vqluspás skildring av den pånyttfödda jorden. Dēnkard sammanfattar: "träd och växter skall ständigt grönska, hela naturen skall glädja sig". ${ }^{\circ}$ De framtida fullkomnarna skall återge träd och växter deras grönska. ${ }^{51}$ Vid förnyelsen kommer även världen att vara full med strömmande vatten..$^{52}$

\section{Slutsats}

Jämförelsen av ragnaröksmyten med den kristna eskatologin visar framför allt på skillnader, både i fråga om slutstriden och förnyelsen, och bidrar på så vis till att den skandinaviska traditionens särprägel blir tydligare. En påverkan från kristen tradition ter sig därför osannolik annat än i vissa detaljer. Än mindre går det att tänka sig att myten om Ragnarök som sådan skulle ha uppstått genom mötet med kristen föreställningsvärld. Skillnader finns också gentemot den iranska religionen och dess kosmiska eskatologi, men här är beröringspunkterna mer påfallande. Dessa likheter kan knappast ha uppstått genom ett iranskt inflytande som några forskare gjort gällande. ${ }^{33} \mathrm{Vi}$ har i stället att göra med två av varandra oberoende eskatologiska traditioner, den skandinaviska och den iranska, vilka uppvisar sina egna särdrag. Kanske har de en gång stått närmare varandra och dragit näring ur samma rötter. 


\section{Noter}

I. Detta förhållande påpekas inte så ofta, men noteras av Steven O'Brien (1976: 296, 300).

2. Saxo Grammaticus, Gesta Danorum ([red.] Friis-Jensen \& [övers.] Zeeberg), 8: kap. I-4 och Sogubrot af nokkrum fornkonungum (netútgáfan): kap. 5-9. Huvudkällan tycks ha varit en dikt om detta slag som av forskningen kallas Bråvalla-kvädet. Dikten kan knappast anses för ett genuint vikingakväde utan torde ha författats på I Ioo-talet (se Bjarni Guðnason I958 och Seip I957).

Stig Wikander (I960a) menade att skildringen återspeglade gammal indoeuropeisk eskatologi (jfr Wikander I960b). Bland dem som godtagit Wikanders tolkning märks Jaan Puhvel (I987: 87-89), Steven O’Brien (I976: 298 f.), och Daniel Bray (2000: 360 ).

3. Ett liknande synsätt företräds även av Vésteinn Ólason (2013) Gísli Sigurðsson (2013).

4. Variabiliteten hör till mytens väsen och har betonats av bl.a. Claude Lévi-Strauss (I958: 240), Raymond Firth (I960), och Igor M. Diakonoff (I995: 43).

5. E. Noreen (I926: 87) betraktade Voluspá som en kompilation av fragment och ansåg det meningslöst att på den grundvalen ge ut en kritisk text. Jón Helgason ((I955) I97I: VIII) anser att de tre textvarianterna utgör oberoende nedteckningar från muntlig tradition. Ursula Dronke (I997: 2) däremot ser en mer komplicerad traderingsprocess i vilken Hauksbók och Snorres strofer byggt på skriftliga versioner. Jag delar Judy Quinns (2000: $88 \mathrm{f}$.) uppfattning om varianternas betydelse för förståelsen av dikten. K. G. Johansson (20I3: I 80) föreslår en datering till mitten av I Ioo-talet. I en liknande datering hamnar Gro Steinsland (2009); jfr Steinsland 2013: I 57.

6. En klargörande diskussion om editeringen av texten till Veluspá ger Quinn 2000.

7. För den iranska kosmiska eskatologin och dess tidsaspeker, se Hultgård 2009.

8. Formen ragna røk framstår som den ursprungliga i fornvästnordiska, och är nästan allenarådande i de poetiska källorna; i Snorres Edda förekommer endast ragnarökkr eller ragnarökr',gudaskymning'; se vidare Haraldur Bernharðsson 2007. 
9. Voluspá 53, 55 och 56 (se Eddadigte I ([red.] Jón Helgason)); Vafprúðnismál 5I, 52 och 53; Lokasenna 58; Hyndlulióð 44; Sonatorrek 24 (se Eddadigte 2 ([red.] Jón Helgason)); Snorri Sturluson, Edda: Gylfaginning [...] [red. Holtsmark \& Jón Helgason]: kap. 5I , avsnitt 6.

IO. Påpekat av Olrik (I902: 206; I922: 54).

I I. Hauksbóks text är på detta ställe delvis bortnött. För ovanstående läsning se Eddadigte I ([red.] Jón Helgason): 44-46.

I 2. Voluspá 53 (se Eddadigte I ([red.] Jón Helgason)); Lokasenna 42 (se Eddadigte 2 ([red.] Jón Helgason)).

I3. Man måste alltid beakta den omständigheten att endast delar av den förkristna mytologin överlevde religionsskiftet.

I4. Olrik (I902: 2II; I922: 59) avvisar bestämt tanken att Snorre bygger på förlorade källor. Kampen mellan Heimdall och Loke, liksom den mellan Tyr och Garm, måste helt skrivas på mytografen Snorres konto. Jan de Vries (I956-57: $\ 354$ ) lämnar frågan om ursprunget till Tyrs och Garms kamp öppen, men förbigår den mellan Heimdall och Loke. J. S. Martin (I972: 8I f.) framhåller osäkerheten i Snorres uppgifter och tenderar att se striden mellan Tyr och Garm som en skapelse av Snorre. Martein Helgi Sigurðsson (2002) menar att Garm redan i Voluspáär densamme som Fenrisulven och att Snorre känt till en kenning där týr d.v.s. Oden kämpat mot Garm, men att han missuppfattat att $t y ́ r$ refererar till Oden och inte till guden Tyr.

I5. Skáldskaparmál (I9, rad I5; se Snorri Sturluson, Edda: Skáldskaparmál ([red.] Faulkes)) säger att "Heimdall stred (deildi) med Loke om Brísingamen" och av Gylfaginning 35 (se Snorri Sturluson, Edda: Gylfaginning [...] ([red.] Holtsmark \& Jón Helgason)) framgår att detta smycke tillhörde Fröja. Strof 2 i Húsdrápa (se Snorri Sturluson, Edda: Skáldskaparmál ([red.] Faulkes)) är mycket omdiskuterad. En del uttolkare går på Snorres linje, medan andra menar att "den fagra havsnjuren" syftar på ett stycke land som höjt sig ur havet. För diskussionen och vidare litteratur, se Heizmann 2009 och Cöllen 20II: 93-II7.

I6. Ortsbeteckningen Harmagedon återgår med all sannolikhet på det hebreiska harmagiddō(n), d.v.s. 'Megiddos berg'. Oklart är dock varför författaren till Uppenbarelseboken valt just denna ortsbeteckning. Möjligen har han varit inspirerad av Sakarja bok, kap. I2, 
som innehåller en profetia om belägringen av Jerusalem och Juda städer. Det sägs att "alla jordens folkslag skall samla sig" mot Jerusalem, men angriparna kommer att förintas genom Jahves ingripande. Efter befrielsen skall man sörja "den som de har genomborrat”, ett mångtydigt uttryck, men troligast syftar det på Israels folk. Sorgehögtiden skall vara lika stor som den man firade över guden Hadad-Rimmon "på Megiddos slätt", babiq'at magiddōn.

I7. Denna onda gestalt kallas också "Laglöshetens människa" och "Fördärvets son". 2 Thessalonikerbrevet har av allt att döma inte Paulus som författare, men brevet står i en paulinsk tradition och är förmodligen skrivet på 80-talet; för diskussionen om äkthet och datering, se Vielhauer 1975: 95-102.

I 8. Det är denna uppfattning, som främst kommer till uttryck i dagens forskning; se Frankfurter I999; vidare Küchler 20 I I; Kowalski 20 I I: 73. Bousset (I 895: I2 f.) menade att Antikrist-bilden hos Hippolytos var "opolitisk" och utan samband med det romerska imperiet.

I9. Ian J. Kirby (I976: 40I-403) förtecknar inga referenser till Uppenbarelseboken I 2: 7-9 och 20: I-3, 7-10. Det finns endast ett citat ur kap. 20 nämligen i Honorius Augustodunensis, Elucidarius ([red.] Firchow \& Grimstad): I35 (3: 73) med domsscenen där det sägs att böcker ska öppnas och de döda dömas utifrån det som där står skrivet (Upp. 20: I2). Från 2 Thessalonikerbrevet förtecknar Kirby (1976: 384) bara ett citat, nämligen inledningen till stället om "Laglöshetens människa" (2: I f.) som är hämtat från Thomas Saga Erkibyskyps (se Kirby 1976: 384; 1980: 82-84).

20. Antikrists framträdande och verksamhet beskrivs ingående i Honorius Augustodunensis, Elucidarius ([red.] Firchow \& Grimstad): I 27-I $29(3: 33-35)$.

2I. Man skulle även kunna tänka sig översättningen "som en gud”. Genom att skriva "gud" med stor bokstav (ut Deum) antyder den latinska förlagan att Antikrist vill träda i Guds ställe.

22. Honorius Augustodunensis, Elucidarius ([red.] Firchow \& Grimstad): I29.

23. Gamal norsk homiliebog ([red.] Indrebø).

24. Muspilli ([red.] Braune \& Ebbinhaus). 
25. Meningen måste vara att Satan låter Antikrist duka under (farsenkan) utan att ingripa, eftersom själva kampen står mellan Elias och Antikrist.

26. Jfr de Vries I956-57: $\mathbb{S} 590$.

27. Se Staiti 2002.

28. Gamal norsk homiliebog ([red.] Indrebø).

29. Honorius Augustodunensis, Elucidarius ([red.] Firchow \& Grimstad).

30. Två bibelställen har påverkat uppfattningen om munnens andedräkt som verksamt förintelsemedel: Jesaja II: 4 att Messias skall förgöra de onda med andedräkten från sina läppar, och 2 Thess. 2: 8 att Herren Jesus skall döda ( $\alpha v \varepsilon \lambda \varepsilon \tilde{i} ;$ Vulg. interficiet) den Laglöse med

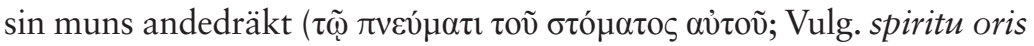
sui). Endast undantagsvis kan man stöta på föreställningen att Antikrist blir dödad med ett vapen, så t.ex. i den syriska Daniel-apokalypsen 24, där änglarna klyver Antikrist i två stycken med ett brinnande svärd (se The Syriac Apocalypse of Daniel ([red. \& övers.] Henze)).

3I. Föreställningen om Jesu nedstigande i dödsriket och hans övervinnande av Djävulen fick tidigt fäste i kristendomen; se W. Boussets (I926: 26-33) utmärkta sammanfattning, där han argumenterar för att en orientalisk myt om en frälsargestalts nedstigande i dödsriket och kamp mot mörkrets makter har förts över på Jesus.

Sättet på vilket Djävulen blir besegrad varierar i traditionen. Bartolomeusevangeliet säger att Jesus gick in och grep Beliar (= Djävulen), piskade honom och band honom i kedjor (Apokryfe evangelier ([övers.] Thomassen): ı 84). Det latinska Nikodemus-evangeliet, en text som blev omåttligt populär i Västeuropa, omtalar att Kristus trampade på Döden, grep Satan och överlämnade honom för alltid i dödsrikets våld (Apokryfe evangelier ([övers.] Thomassen): 248-250). Den norröna versionen berättar att Kristus gillrade en fälla för Satan i Jerusalem på så sätt att han gömde en fiskkrok i agnet och dolde reven. När Satan kom för att sluka Jesus på korset, fastnade han på kroken. Då uppenbarade sig Vår Herre (dominus noster) och band Satan och bad sina änglar vakta honom (Soga om nedstiginga $i$ Dødsriket ([red. \& övers.] Haugen): I 8-2 I).

32. Så Hintze I994: 43; P. O. Skjærvø (1994: 202) sätter den Yngre Avestas tillblivelse till mellan 900 och $400 \mathrm{f}$. Kr. 
33. Den avestiska texten till detta ställe i Yašt I9 ger ordet vaē $\delta a-$, ett hapax legomenon, som sannolikt är en korrupt form för vazra-; se diskussionen i Humbach \& Ichaporia I998: I66. Ordet vazra- betecknar av allt att döma en slags yxa (så P. O. Skjærvø i Zarathustras sanger ([övers.] Skjærvø): I6I) och är även guden Mithras favoritvapen beskrivet i Yašt I0, 96 och I32. Senare tradition har tolkat vapnet som en stridsklubba (mir. warz och nypers. gurz).

34. Olrik r9I4: I78 f.; I922: 337 f.; Dumézil I959: 83; Ström I967: I9I.

35. Ohrmazd och Ahreman är de medeliranska språkformerna för Ahura Mazdā, respektive Ayra Mainyu

36. Se även Wizìdagīhà $\bar{\imath}$ Zàdspram 34: 44; Zand $\bar{\imath}$ Wahman Yasn VI: Iо-I 3 ; Dēnkard VII, I I: 3 .

37. För denna åskådning och dess sociala roll, se Hultgård 20 I I.

38. Beträffande källorna till deras kristendom, se Hultgård, 20 I : 3०8-3 I2.

39. The Patrician Texts in the Book of Armagh ([red. \& övers.] Bieler); Tiréchan, kap. I2. Ordet erdathe och dess etymologi är inte utrett, se The Patrician Texts in the Book of Armagh ([red. \& övers.] Bieler): 2 I 8 .

40. Den möjligheten antyder även Olrik I902: 22I; I922: 68.

4I. Förnyelsen omtalas i Voluspá 59-65 (se Eddadigte I ([red.] Jón Helgason)); Vafprúdnismál 44-47, 50-5 I (se Eddadigte 2 ([red.] Jón Helgason)); Snorri Sturluson, Edda: Gylfaginning [...] ([red.] Holtsmark \& Jón Helgason): kap. 53.

42. Vafprúdnismál 5I (se Eddadigte 2 ([red.] Jón Helgason)).

43. För en sammanfattning av Torshammaren som symbol, se Hultgård I999.

44. Dessa runstenar är: Velanda ( $V g$ I 50$)$; Glavendrup ( $D R$ 209); Virring ( $D R$ I IO) samt Sønder Kirkeby ( $D R$ 220).

45. Voluspá 63 (se Eddadigte I ([red.] Jón Helgason)). Betydelsen av sammansättningen hlautviðr, ett hapax legomenon, är oklar och hänger till stor del på vilken innebörd ordet blaut har i detta sammanhang. Här torde det ange ett föremål, en "lott", i ett divinationsförfarande. 
Jag tolkar hlautviðr som en motsvarighet till det fruktbärande träd som germanerna enligt Tacitus skildring (Germania [red. Önnerfors], kap. Io) tog en gren ifrån för att använda i sina lottorakel. För denna strof i Voluspá, se Hultgård 2015.

46. Detta betonas särskilt av Meulengracht Sørensen 2000: 34I.

47. Några kommentatorer ser i de fiskar som örnen fångar laxar: Finnur Jónsson i Völuspá / Völvens spådom ([övers.] Finnur Jónsson): I7; densamme i [Sveinbjörn Egilsson \& Finnur Jónsson] (I860) I9I3-I6: I34; Dronke i The Poetic Edda 2 ([red. \& övers.] Dronke): 59.

48. Se Meulengracht Sørensen 2000: $344 \mathrm{f}$.

49. Utsagan är inspirerad av Jesaja 65: I7 där det sägs att "nu skapar jag en ny himmel och en ny jord" men den följande beskrivningen handlar mest om det utvalda Gudsfolkets lycka och goda liv i Israels land.

50. Dēnkard VII, I I: 4: hamēšag urwar zargōn waxšišn, ham dahišn urwāhmanīh bawēnd.

51. Bundahišn 33: 29 och 32: ō urwarān zargōnīh dahēd.

52. Dēnkard VII, 9: 23: axw ì astōmand [...] purr āšixt ēstēd.

53. Reitzenstein I924 och Peuckert I935; för vissa delar av ragnaröksmyten även Olrik I902; I9I4; I922.

\section{Referenser}

Källor

Apokryfe evangelier [I00-t.-300-t.] (Verdens hellige skrifter). [Övers.] Einar Thomassen. Oslo 200I: De norske bokklubbene.

[Bibeln.] Bibel 2000. Uppsala 2000: Svenska Bibelsällskapet.

Bundahišn = Zand-Ākāsīh: Iranian or Greater Bundahišn. [Red. \& övers.] Behramgore T. Anklesaria. Bombay I956: Rahnumae Mazdayasnan Sabha.

Dēnkard $=$ Dēnkart: A Pablavi Text. Facsimile ed. of the Manuscript B of the K. R. Cama Oriental Institute, Bombay. [Red.] Mark J. Dresden. Wiesbaden I966: Harrassowitz.

$D R=$ Danmarks runeindskrifter. Atlas. Text. [Utg.] Lis Jacobsen \& Erik Moltke. København I94I-42: Munksgaard. 
[Eddan] Eddadigte [80o-t.-Iooo-t.]. I, Voluspá. Hávamál (Nordisk filologi A. Tekster 4). [Red.] Jón Helgason. Oslo (I95 5) I97 I: Dreyer. - Eddadigte. 2, Gudedigte (Nordisk filologi A. Tekster 7). [Red.] Jón Helgason. Oslo (I956) I97I: Dreyer.

The Poetic Edda. 2, The Mythological Poems. [Red. \& övers.] Ursula Dronke. Oxford I997: Clarendon Press.

Elucidarius, se Honorius Augustodunensis

GNH = Gamal norsk homiliebog: Cod AM 6I9 [ca I200] (Skrifter utgitt for Kjeldeskriftfondet 54). [Red.] Gustav Indrebø. Oslo I93 I: Jacob Dybwad.

Honorius Augustodunensis [d. ca I I 56], Elucidarius in Old Norse Translation (Rit 36). [Red.] Evelyn Scherabon Firchow \& Kaaren Grimstad. Reykjavík I989: Stofnun Árna Magnússonar.

$I H B=$ [Íslensk hómilíubók] The Icelandic Homily Book: Perg. I5 $4^{\circ}$ in the Royal Library, Stockholm [ca I 200] (Íslensk handrit 3). [Red.] Andrea de Leeuw van Weenen. Reykjavík I993: Stofnun Árna Magnússonar á Íslandi.

Muspilli [ca 870]. Althochdeutsches Lesebuch, s. 86-89. [Red.] Wilhelm Braune \& Ernst A. Ebbinhaus. Tübingen (I875) I994: Niemeyer. (I7 uppl.)

Novum Testamentum Graece (Universität Münster, Institut für neutestamentliche Textforschung). [Red.] Eberhard \& Erwin Nestle, Barbara \& Kurt Aland. Stuttgart 20 I 2: Deutsche Bibelgesellschaft. (28 uppl.)

The Patrician Texts in the Book of Armagh [800-t.] (Scriptores Latini Hiberniae ro). [Red. \& övers.] Ludwig Bieler. Dublin (I979) 2004: Dublin Institute for Advanced Studies.

Saxo Grammaticus [d.ca I 220], Gesta Danorum / Danmarkshistorien I. [Red.] Karsten Friis-Jensen. [Övers.] Peter Zeeberg, Gylling 2005: Det Danske Sprog- og Litteraturselskab \& Gads Forlag.

Snorri Sturluson [d. I24I], Edda: Gylfaginning og prosafortellingene av Skáldskaparmál (Nordisk Filologi A. Tekster I). [Red.] Anne Holtsmark \& Jón Helgason. København (I950) I968: Munksgaard. 
— Edda: Skáldskaparmál. I, Introduction, Text and Notes. [Red.] Anthony Faulkes. London 1998: Viking Society for Northern Research.

Soga om nedstiginga i Dødsriket / Niðrstigningar saga. Norrøne tekster $i$ utval, s. 250-265. [Red. \& övers.] Odd Einar Haugen. Oslo I994: Ad Notam Gyldendal.

The Syriac Apocalypse of Daniel (Studien und Texte zu Antike und Christentum I I). [Red. \& övers.] Mattias Henze. Tübingen 200I: Mohr Siebeck.

Sögubrot af nokkrum fornkonungum i Dana ok Svíaveldi [sl. av I 200-t.] (Netútgáfan). http://www.snerpa.is/net/forn/sogubrot.htm (tillgänglig 5.5.20I4).

Tryggðamál. Eddica minora: Dichtungen eddischer Art aus den Fornaldarsögur und anderen Prosawerken, s. I29-I33. [Red.] Andreas Heusler \& Wilhelm Ranisch. Dortmund I903: Fr. Wilh. Ruhfus.

$V g=$ Västergötlands runinskrifter (Sveriges runinskrifter 5: I). D. I, Text. [Red.] Hugo Jungner \& Elisabeth Svärdström. Stockholm I958-70: Almqvist \& Wiksell International.

Vulgata = Biblia Sacra: Iuxta Vulgatam Versionem. I-2. [Red.] Bonifatius Fischer et al. Stuttgart I969: Württembergische Bibelanstalt.

Völu-spá / Völvens spådom [900-t.?-I Ioo-t.?] (Studier fra Sprog- og oldtidsforskning 84). [Övers.] Finnur Jónsson. København I9I I: Tillge's boghandel.

Wizìdagīhā $\bar{\imath}$ Zādspram > Zādspram

Zādspram [800-t.] [Wizìdagīhā ̄̇ Zādspram] Anthologie de Zādspram (Studia iranica I3). [Red. \& övers.] Philippe Gignoux \& Ahmad Tafazzoli. Paris I993: Association pour l'avancement des études iraniennes.

Zand $\bar{\imath}$ Wahman Yasn. The Zand $\bar{\imath}$ Wahman Yasn: A Zoroastrian Apocalypse (Serie orientale Roma 75), s. 35-76. [Red.] Carlo G. Cereti. Roma I995: Istituto italiano per il medio ed estremo oriente.

Zarathustras sanger: de eldste iranske skriftene [1000-800 f.Kr.] (Verdens hellige skrifter). [Övers.] Prods Octor Skjærvø. Oslo 2003: De norske bokklubbene. 


\section{Sekundärlitteratur}

Der Antichrist: historische und systematische Zugänge (Studien zur christlichen Religions- und Kulturgeschichte I4). [Red.] Mariano Delgado \& Volker Leppin. Fribourg: Academic Press / Stuttgart: Kohlhammer.

Bjarni Guðnason. I958. Um Brávallapulu. Skírnir I32, s. 82-I 28.

Bousset, Wilhelm. I895. Der Antichrist in der Überlieferung des Judentums, des neuen Testaments und der alten Kirche: ein Beitrag zur Auslegung der Apokalypse. Göttingen: Vandenhoek \& Ruprecht.

- (I916) I926. Kyrios Christos: Geschichte des Christusglaubens von den Anfängen des Christentums bis Irenaeus (Forschungen zur Religion und Litteratur des Alten und Neuen Testaments, N.F. 4). Göttingen: Vandenhoek \& Ruprecht. (3 uppl.)

Bray, Daniel. 2000. The end of mythology: Hesiod's Theogony and the Indo-European myth of the final battle. Journal of Indo-European Studies 28, s. 359-37I.

Cöllen, Sebastian. 20I I. Der rätselhafte Gott: Heimdallr im Licht altnordischer Vorstellungen von Abnen und Ordnung. Uppsala: Uppsala universitet.

Diakonoff, Igor M. (1990) I995. Archaic Myths of the Orient and the Occident (Orientalia Gothoburgensia Io). Göteborg: Göteborgs universitet.

Dronke, Ursula. 1997. The Poetic Edda. 2, The Mythological Poems. [Red. \& övers.] Ursula Dronke. Oxford: Clarendon Press.

Dumezil, Georges. 1959. Les dieux des Germains: essai sur la formation de la religion scandinave (Mythes et religions 38). Paris: Presses universitaires de France.

Firth, Raymond. I960. The plasticity of myth: cases from Tikopia. Ethnologica 2, s. I 8 I-I 88 .

Frankfurter, David. I999. Introduction. The Antichrist Legend: A Chapter in Christian and Jewish Folklore (American Academy of Religion. Texts and Translations Series 24), s. "iii-"xx. [Av] Wilhelm Bousset, [övers.] A. H. Keane. Atlanta, GA: Scholars Press. 
Gísli Sigurðsson. 2013. Vọluspá as the product of an oral tradition: what does that entail? The Nordic Apocalypse, s. 45-62.

Haraldur Bernharðsson. 2007. Old Icelandic ragnarök and ragnarökkr. Verba Docenti: Studies in Historical and Indo-European Linguistics Presented to Jay H. Jasanoff by Students, Colleagues, and Friends, s. 25-38. [Red.] Alan J. Nussbaum. Ann Arbor: Beech Stave Press.

Heizmann, Wilhelm. 2009. Der Raub des Brísingamen, oder: worum geht es in Húsdrápa 2? Analecta Septentrionalia: Beiträge zur nordgermanischen Kultur- und Literaturgeschichte (Ergänzungsbände zum Reallexikon der germanischen Altertumskunde 65), s. 502530. [Red.] Wilhelm Heizmann \& Klaus Böldli \& Heinrich Beck. Berlin: de Gruyter.

Hinze, Almut. I994. Der Zamyād-Yašt (Beiträge zur Iranistik I 5). Wiesbaden: Reichert.

Hultgård, Anders. I999. Hammer. 2, religionsgeschichtliches. Reallexikon der germanischen Altertumskunde I3, s. 486-492. [Red.] Heinrich Beck \& Dieter Geuenich \& Heiko Steuer \& Dieter Timpe. Berlin: de Gruyter.

2009. Le «jour de Dieu» et les «millénaires de Dieu»: deux types d'eschatologie iranienne. Le Jour de Dieu / Der Tag Gottes (Wissenschaftliche Untersuchungen zum Neuen Testament I: 245), s. 43-64. [Red.] Anders Hultgård \& Stig Norin. Tübingen: Mohr Siebeck.

20II. Óðinn, Valhǫll and the Einherjar: eschatological myth and ideology in the late Viking period. Ideology and Power in the Viking and Middle Ages: Scandinavia, Iceland, Ireland, Orkney, and the Faeroes (The Northern World 52), s. 297-328. [Red.] Gro Steinsland \& Jón Viðar Sigurðsson \& Jan Erik Rekdal \& Ian Beuermann. Leiden: Brill.

20I 5. När gudar faller: ragnaröksmyten och dess ursprung. Uppsala.

Humbach, Helmut \& Pallan R. Ichaporia. I998. Zamyād Yasht: Yasht I9 of the Younger Avesta. Wiesbaden: Harrassowitz.

Johansson, Karl G. 20I3. Voluspá, the Tiburtine Sibyl, and the apocalypse in the north. The Nordic Apocalypse, s. I6I-I 84 . 
Jón Helgason. (I955) I97I. Innledning. Eddadigte. I, Vọluspá. Hávamál (Nordisk filologi A. Tekster 4), s. I-XVII. [Red.] Jón Helgason. Oslo: Dreyer.

Kirby, Ian J. 1976. Biblical Quotation in Old Icelandic-Norwegian Religious Literature. I, Text (Rit 9). Reykjavík: Stofnun Árna Magnússon.

I980. Biblical Quotation in Old Icelandic-Norwegian Religious Literature. 2, Introduction (Rit Io). Reykjavík: Stofnun Árna Magnússon.

Kowalski, Beate. 20II. Der Antichrist im Neuen Testament. Der Antichrist: historische und systematische Zugänge, s. 65-100.

Küchler, Max. 20II. Der Antichrist in der frühen jüdischen Apokalyptik und in der zwischentestamentlichen Zeit. Der Antichrist: historische und systematische Zugänge, s. 53-64.

Lévi-Strauss, Claude. I958. Anthropologie structurale. Paris: Plon.

Marteinn Helgi Sigurðsson. 2002. Týr: The One-Handed WarGod. Cambridge: Department of Anglo-Saxon, Norse and Celtic, University of Cambridge.

Martin, John Stanley. 1972. Ragnargk: An Investigation into Old Norse Concepts of the Fate of the Gods (Melbourne Monographs in Germanic Studies 3). Assen: Van Gorcum.

Meulengracht Sørensen, Preben 2000. Flygr oqrn yfir: til strofe 59 i Voluspá. International Scandinavian and Medieval Studies in Memory of G. W. Weber (Hesperides I2), s. 339-346. [Red.] Michael Dallapiazza et al., Trieste: Parnaso.

The Nordic Apocalypse: Approaches to Voluspá and Nordic Days of Judgement (Aberdeen Studies in the Scandinavian World 2). [Red.] Terry Gunnell \& Annette Lassen. Turnhout 20I3: Brepols.

Noreen, Erik. I926. Den norsk-isländska poesien. Stockholm: Norstedt.

O'Brien, Steven. 1976. Indo-European eschatology: a model. Journal of Indo-European Studies 4, s. 295-320.

Olrik, Axel. I902. Om Ragnarok. Årbøger for nordisk oldkyndighed og historie I 902, s. I 57-29I. 
__ I9I4. Om Ragnarok. 2, Ragnaroksforestillingernes udspring. København: Gad.

I922. Ragnarök: die Sagen vom Weltuntergang. [Övers.] Wilhelm Ranisch. Berlin: de Gruyter.

Peuckert, Will-Erich. I935. Germanische Eschatologien. Archiv für Religionswissenschaft 32, s. I-37.

Puhvel, Jaan. 1987. Comparative Mythology. Baltimore: Johns Hopkins University Press.

Quinn, Judy. 2000. Editing the Edda: the case of Voluspá. Scripta Islandica 5I, s. 69-92.

Reitzenstein, Richard. I924. Weltuntergangsvorstellungen: eine Studie zur vergleichenden Religionsgeschichte. Kyrkohistorisk årsskrift 24, s. I 29-2 I 2.

Seip, Didrik Arup. I957. Bråvallaslaget. Kulturhistoriskt lexikon för nordisk medeltid 2, sp. 295-297. Malmö: Allhem.

Skjærvø, Prods Oktor. I994. Hymnic composition in the Avesta. Die Sprache 36, s. 199-243.

Staiti, Chiara. 2002. Muspilli. Reallexikon der germanischen Altertumskunde 20, s. 433-438. [Red.] Heinrich Beck \& Dieter Geuenich \& Heiko Steuer. Berlin: de Gruyter.

Steinsland, Gro. 2009. Vqluspá: a source to Norse pagan mythology or a Christian revelation in disguise of a classical Sibylline oracle? Confluence (Interdisciplinary Communications 2007/2008), s. 98-Ior. [Red.] Willy Østreng. Oslo: Centre for Advanced Study at the Norwegian Academy of Science and Letters.

2013. Voluspá and the Sibylline Oracles with a focus on the 'Myth of the Future'. The Nordic Apocalypse, s. I47-I60.

Ström, Åke V. I967. Indogermanisches in der Völuspá. Numen I4, s. I $67-208$.

[Sveinbjörn Egilsson \& Finnur Jónsson.] (I860) I9I3-16. Lexicon poeticum antiquae linguae Septentrionalis / Ordbog over det norsk-islandske skjaldesprog. Forfattet af Sveinbjörn Egilsson. Forøget og påny udgivet ved Finnur Jónson. København: Det kongelige nordiske oldskriftselskab. 
Vésteinn Ólason. 2013. Voluspá and time. The Nordic Apocalypse, S. $25-44$.

Vielhauer, Philipp. I975. Geschichte der urchristlichen Literatur: Einleitung in das Neue Testament, die Apokryphen und die Apostolischen Väter (de Gruyter Lehrbücher). Berlin: de Gruyter.

de Vries, Jan. I956-57. Altgermanische Religionsgeschichte. I-2 (Grundriss der germanischen Philologie I2: I-2). Berlin: de Gruyter. (2 uppl.)

Wikander, Stig. I960a. Från Bråvalla till Kurukshetra. Arkiv för nordisk filologi 59, s. I83-193.

I96ob. Germanische und indo-iranische Eschatologie. Kairos 2, s. $83-88$. 